\title{
Assessment of glass fiber-reinforced polyester pipe powder in soil improvement
}

\author{
Baki BAĞRIAÇIK ${ }^{\mathrm{a}}$, Ahmet BEYCIOĞLU ${ }^{\mathrm{b}}$, Szymon TOPOLINSKI ${ }^{\mathrm{c}}$, Emre AKMAZ ${ }^{\mathrm{d}}$, Sedat SERT $^{\mathrm{e}}$, Esra \\ Deniz GÜNER ${ }^{f}$ \\ ${ }^{a}$ Department of Civil Engineering, Çukurova University, Adana 01330, Turkey \\ ${ }^{b}$ Department of Civil Engineering, Adana Alparslan Türkeş Science and Technology University, Adana 01250, Turkey \\ ${ }^{c}$ Department of Civil Engineering, UTP Science and Technology University, Bydgoszcz 85796, Poland \\ ${ }^{d}$ Geoenvironmental Infrastructure (SGI) Research Group, George Mason University, Fairfax, VA 22030, USA \\ ${ }^{e}$ Department of Civil Engineering, Sakarya University, Sakarya 54187, Turkey \\ ${ }^{f}$ Department of Environmental Engineering, Çukurova University, Adana 01330, Turkey \\ *Corresponding author. E-mail: bakibagriacik@gmail.com
}

(C) The Author(s) 2021. This article is published with open access at link.springer.com and journal.hep.com.cn

\begin{abstract}
This study investigates the use of glass fiber-reinforced polyester (GRP) pipe powder (PP) for improving the bearing capacity of sandy soils. After a series of direct share tests, the optimum PP addition for improving the bearing capacity of soils was found to be $12 \%$. Then, using the optimum PP addition, the bearing capacity of the soil was estimated through a series of loading tests on a shallow foundation model placed in a test box. The bearing capacity of sandy soil was improved by up to $30.7 \%$. The ratio of the depth of the PP-reinforced soil to the diameter of the foundation model $(H / D)$ of 1.25 could sufficiently strengthen sandy soil when the optimum PP ratio was used. Microstructural analyses showed that the increase in the bearing capacity can be attributed to the chopped fibers in the PP and their multiaxial distribution in the soil. Besides improving the engineering properties of soils, using PP as an additive in soils would reduce the accumulation of the industrial waste, thus providing a twofold benefit.
\end{abstract}

KEYWORDS shallow foundation, sandy soil, bearing capacity, soil improvement, pipe powder

\section{Introduction}

Soil plays an important role in maintaining the structural integrity of buildings; hence, studies regarding the improvement of the engineering performance of soil are vital in the construction and, subsequently, in the service life of buildings. Therefore, in situ examination of soil conditions and improvement of their physical and mechanical properties are essential to meet the engineering demands [1]. Moreover, considering the increasing population and their needs, the engineering properties of natural soils are inadequate. Owing to the worldwide urbanization and population growth, geotechnical engineers are faced with various soil problems, including total and differential settlements and the low bearing capacity of foundations, poor mechanical parameters of subgrade

Article history: Received Oct 17, 2020; Accepted Feb 17, 2021 layers, and insufficient shear strength. There is also a need for soil improvement in several other civil engineering applications, such as sub-base and subgrade construction, rail and road construction, foundation construction and embankments, backfill for bridge abutments, and retaining walls. In general, soil improvement can be very effective and useful in resolving geotechnical problems. Stabilization can be employed in natural soils to improve their mechanical strength, compressibility, permeability, plasticity, and durability. There are physical, mechanical, chemical, and biological methods available for soil stabilization [2-6]. To date, various techniques and several kinds of materials have been used to solve geotechnical problems [7,8]. Soil stabilizing agents include several materials, such as lime, Portland cement, industrial byproducts (e.g., fly ash and slag), polymers, fibers, chemical reagents, recycled/waste materials (e.g., shredded 
tires and crushed glass), asphalt emulsion, tar, bitumen, etc $[2,4,6,9]$. Because soil is very important in the field of civil engineering, improving its properties has always attracted research attention. Most previous studies focused on adding various materials to stabilize weak soils. In geotechnical engineering, comprehensive study results have shown that soil improvement techniques include in situ stabilization (mechanical improvement of the original soil in the field) and ex situ stabilization (replacement with soils having better geotechnical properties). However, ex situ stabilization methods are not costefficient and easily applied in the field. In contrast, an optimum solution could be achieved using in situ stabilization methods. The main purpose of using waste or recycled materials is not only to reduce landfill stockpile volume and construction costs but also to provide sustainable environmental benefits. Industrial waste materials have been employed as additives to improve the properties of soils. In previous studies on soil improvement, some additives that were commonly used for this purpose, including recycled asphalt pavement (RAP) $[10,11]$, cement by-pass dust, also known as cement kiln dust (CKD) [12,13], pond ash (PA) [14], steel slag (SS) [15-17], end-of-life tires (ELT) [18-20], fly ash (FA) $[21,22]$, rice husk ash (RHA) [23,24], waste stone powder (WSP) $[25,26]$, construction and demolition waste (CDW) [27-29], waste glass (WG) [30-33], and coffee wastes (CW) $[34,35]$. These studies have shown that using recycled or waste materials is effective in increasing the engineering properties of soil mixtures and providing a quality control method for their applications in the field. The above-cited studies acknowledge the potential benefit of using waste/recycled materials for soil improvement.

Pipe powder (PP) is a waste material from the cutting and milling of glass fiber-reinforced polyester (GRP) composite pipes during manufacture. Recently, pipe factories have accumulated a considerable amount of PP waste. According to the literature, there is no clear statistical information on the amount of PP resulting from GRP pipe manufacturing. The factory supporting (Superlit Pipe Industry) this study reported the amount of PP emerging from manufacturing as 31.9, 41.2, 73.1, 134.4, and 133.6 tons in 2015, 2016, 2017, 2018, and 2019 , respectively [36]. Studies on the use of PP in soil improvement are quite limited in the literature. In this study, we focused on the effectiveness of PP in improving poorly graded sandy soils. We investigated PP as an alternative green additive material in sandy soil improvement projects.

\section{Materials and methods}

\subsection{Materials}

A sandy soil sample was collected from the Seyhan riverbed in Adana City (Turkey). The soil sample was classified as poorly graded sand (SP) according to ASTM D 6913-04 [37]. Its gradation curve is shown in Fig. 1. The particle size distribution shows that it is composed of approximately $100 \%$ sand. In addition, the specific gravity was 2.68 and the minimum and maximum dry unit weights were 15.03 and $17.06 \mathrm{kN} / \mathrm{m}^{3}$, respectively [38-40]. The chemical composition of the sample, as determined by $\mathrm{X}$-ray diffraction analysis, is presented in Table 1.

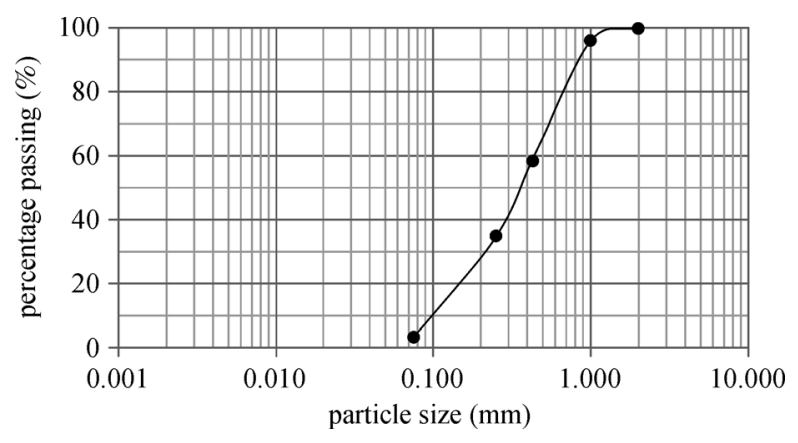

Fig. 1 Sieve analysis of sandy soil.

Table 1 Chemical composition of the sandy soil

\begin{tabular}{lc}
\hline component & percentage (\%) \\
\hline $\mathrm{SiO}_{2}$ & 96.15 \\
$\mathrm{Al}_{2} \mathrm{O}_{3}$ & 2.10 \\
$\mathrm{Fe}_{2} \mathrm{O}$ & 0.60 \\
$\mathrm{MgO}$ & 0.04 \\
$\mathrm{CaO}$ & 0.22 \\
$\mathrm{~K}_{2} \mathrm{O}$ & 0.39 \\
$\mathrm{Na}_{2} \mathrm{O}$ & 0.07 \\
\hline
\end{tabular}

The scanning electron microscope (SEM) image (Fig. 2) shows micro-sized chopped glass fibers (micro-CGFs) in the PP matrix. Owing to the micro-CGFs, we focused on improving soil performance using the PP as a substitutional material. Likewise, using PP in engineering materials has also gained the attention of other researchers $[41,42]$.

\subsection{Methods}

This study was conducted in stages. In the first experimental stage, the fundamental engineering properties of the sandy soil (with and without PP substitution) and an optimum ratio for PP substitution were determined. In the second stage, the performance of the sandy soil was observed through a model test. In the model test, a cylindrical model test box $600 \mathrm{~mm}$ in height and $600 \mathrm{~mm}$ in diameter was filled with the soil sample (with and without PP). The bearing capacity of the soils was determined through a footing placed on the model test 


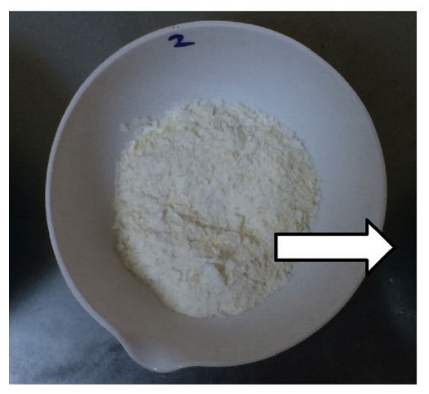

(a)

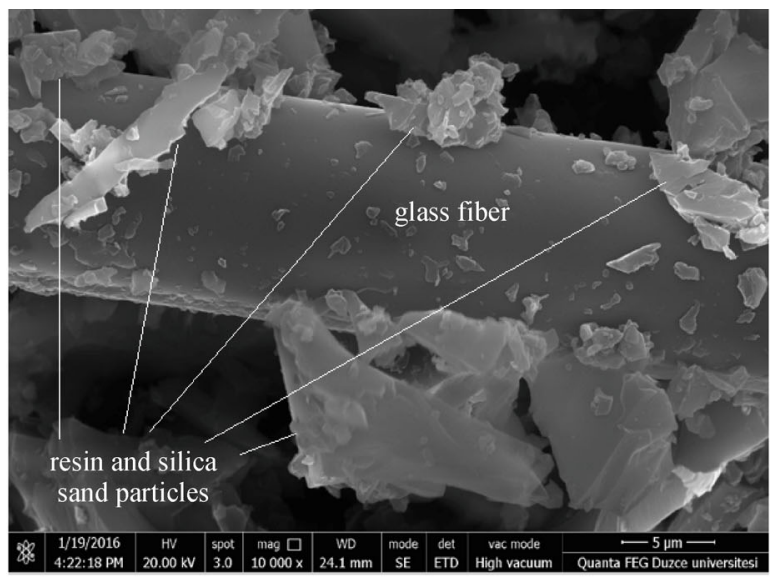

(b)

Fig. 2 (a) PP sample; (b) SEM image of PP.

box. The PP was directly mixed with the sand at the optimum ratio.

\subsubsection{Fundamental testing of soils}

All mixtures containing PP in the weight ratio of $2 \%, 4 \%$, $6 \%, 8 \%, 10 \%, 12 \%, 14 \%, 16 \%$, and $18 \%$ were prepared using the optimum water content (Fig. 3). The shear strength parameters (cohesion and internal friction angles ( $c$ and $\varphi$ values)) were determined by a direct shear test on the reference and PP-substituted soil samples according to ASTM D3080 [43]. A shear box having the dimensions of $60 \mathrm{~mm} \times 60 \mathrm{~mm}$ cross-section and $25 \mathrm{~mm}$ in depth was used in the tests. The tests were conducted at normal vertical stresses of 28,56 , and $116 \mathrm{kN} / \mathrm{m}^{2}$ to completely define the shear strength parameters. The loading rate was $0.002 \mathrm{~mm} / \mathrm{s}$. The shear stresses were recorded as a function of the horizontal displacement up to the maximum value. Details of the direct shear test are depicted in Fig. 4.

\subsubsection{Model test}

The bearing capacity and settlement values of the footing on the soil samples (with and without PP substitution) were determined using the test model. In this test, a cylindrical model test box of $600 \mathrm{~mm}$ in height and $600 \mathrm{~mm}$ diameter was used (number "9" in Figs. 5(a) and 5(b)). Loads were applied through model shallow footing (number " 6 " in Fig. 5(a)). The loads were applied vertically on a plate 5 $\mathrm{mm}$ thick and $100 \mathrm{~mm}$ in diameter ( $D$ in Fig. 5(b)). A model shallow footing that creates no boundary effect in the selected model test box was chosen. Strain gauges were attached to the edges of the test case. We ensured that the applied load did not reach the edges of the case to ensure

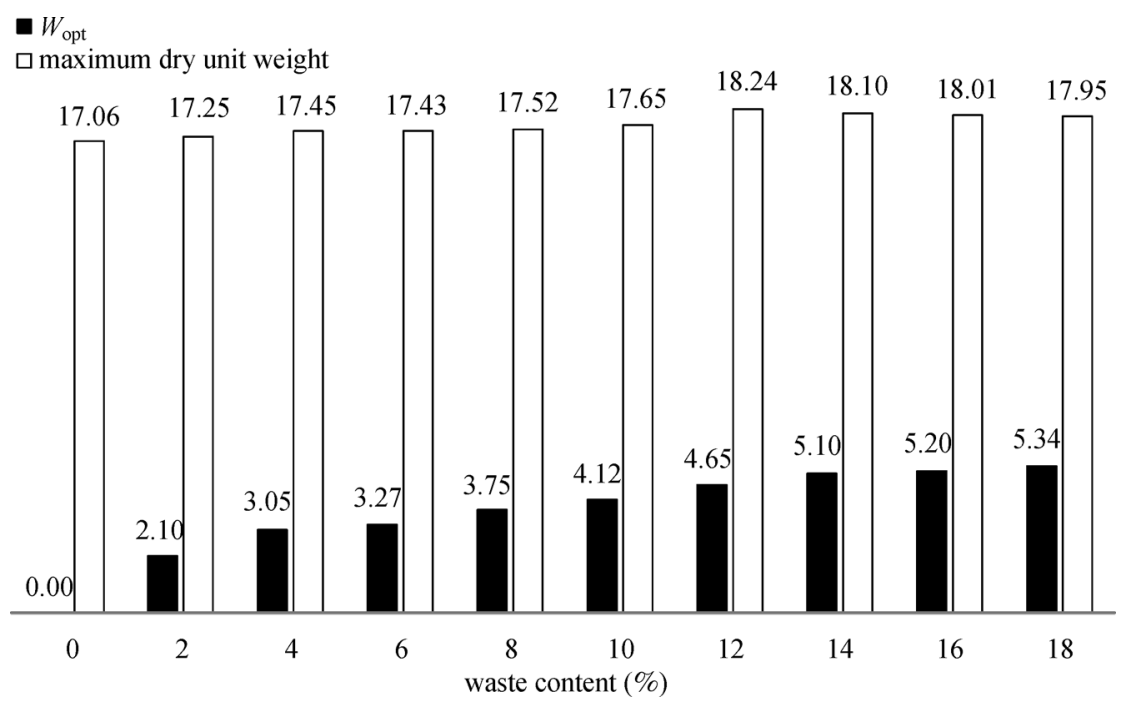

Fig. $3 W_{\text {opt }}$ (optimum water content) $(\%)$ and $\gamma_{\mathrm{kmax}}$ (maximum dry unit weight) $\left(\mathrm{kN} / \mathrm{m}^{3}\right)$ for various PP ratios. 


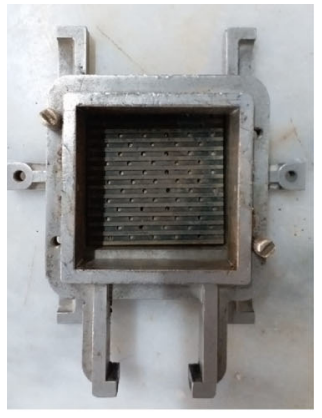

(a)

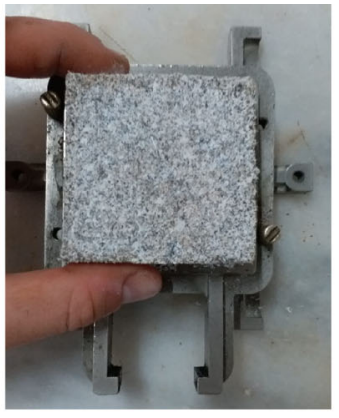

(b)

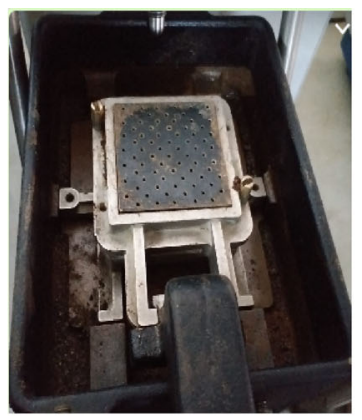

(c)

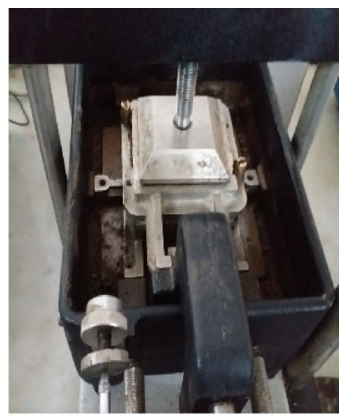

(d)

Fig. 4 Direct shear test on the soil samples: (a) sample mold; (b) sample used in experiments; (c) and (d) placement of porous stonesinstallation head.

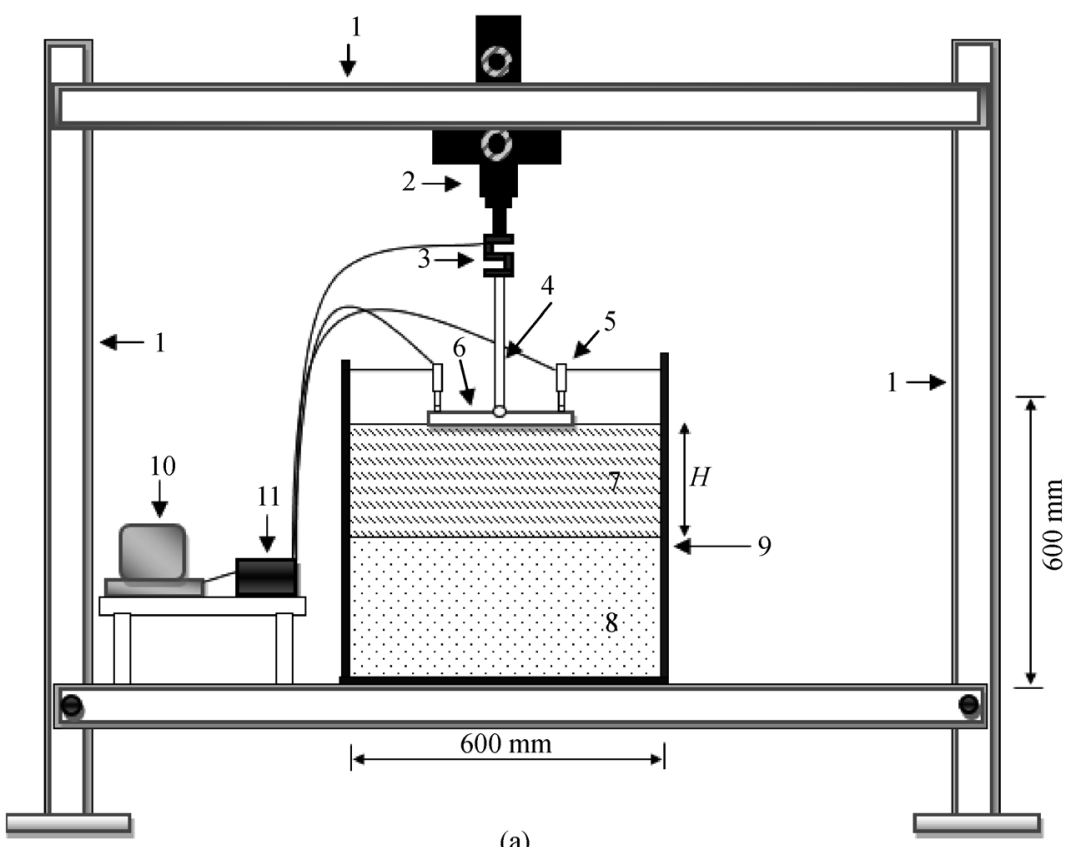

(a)

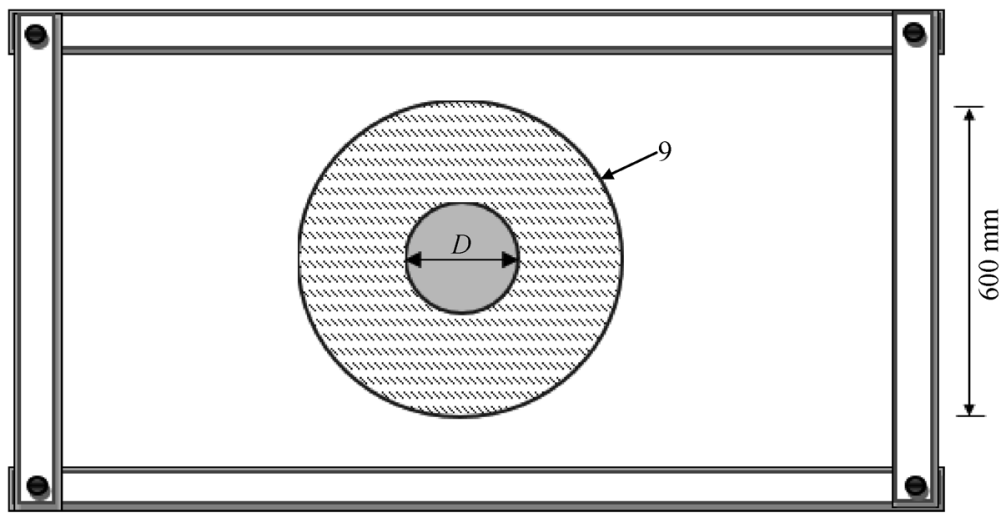

(b)

1: loading frame

2: motor controlled loading system

3: load cell

4: loading head

6: model footing

7,8 : test layers*

9: test box

10: computer

5: displacement transducer

11: data collection unit

Fig. 5 Model test setup: (a) general illustration; (b) top view of the test. 
that no boundary effects are observed. The force applied on the shallow foundation was recorded by an electronic loadcell (Fig. 5(a), number "3"). During the loading of the foundation, the displacements were recorded by two LVDTs (Linear variable differential transformer) (number "5" in Fig. 5(a)) placed on the right and left sides of the foundation plate. At each load level, the displacements formed on the base of the shallow foundation model were measured at these two points equidistant to the center of the foundation, and the settlement values were determined as the average of the two readings. The loading was applied vertically and statically to the center of the plate until the peak value was reached, and the displacement at each load stage was recorded. After loading the foundation, a data logger recorded both the load and the corresponding displacement data. These data were then converted to digital data by the DS7 program (Fig. 5(a) numbers "10" and "11"). Finally, the vertical loadsettlement curve and bearing capacity were determined for each sample.

\section{Results and discussion}

\subsection{Fundamental engineering properties of soils}

All the soil samples were subjected to the direct shear test according to ASTM D3080 [43], and the shear stresshorizontal displacement curves obtained under normal stresses of 28, 56 and $116 \mathrm{kN} / \mathrm{m}^{2}$ are shown in Figs. 6(a)6(c).

The maximum shear strength for each normal stress was determined (Fig. 6). The shear stress-horizontal displacement curves show that the reference samples exhibited the minimum shear stress, especially at the peak points of the curves. The results show that the PP substitution increased the shear strength of the sandy soil sample. To determine the $c$ and $\varphi$ parameters from the slope of the lines, the normal and shear stress relation graphs were plotted using the peak points of the shear stress-horizontal displacement graphs (Fig. 7).

Changes in the $c$ and $\phi$ parameters are given in Table 2, obtained according to the PP substitution ratios to evaluate the effect of PP on the engineering properties of the sandy soil. Figure 8 compares the significant effects of the variation in the PP ratio on shear and $\phi$ vertical stresses.

As shown in Table 2, increasing the ratio of PP in the soil mixture significantly increased the values of $c$ (from 0.75 to $6.69 \mathrm{kN} / \mathrm{m}^{2}$ ) and $\phi$ (from $38.30^{\circ}$ to $39.30^{\circ}$ ). It shows that $\phi$ and $c$ increased by 1.02 and 8.92 , respectively, compared to the values for the reference sample.

Analyzing the effect of PP substitution ratios on the soil performance, a significant increase in shear strength was observed for up to $12 \%$ substitution in all loads. There was

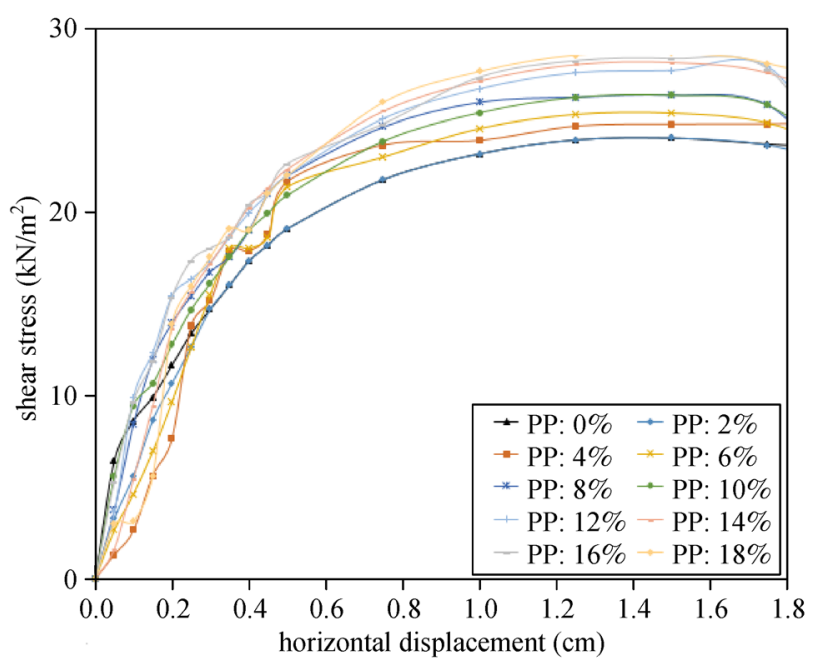

(a)

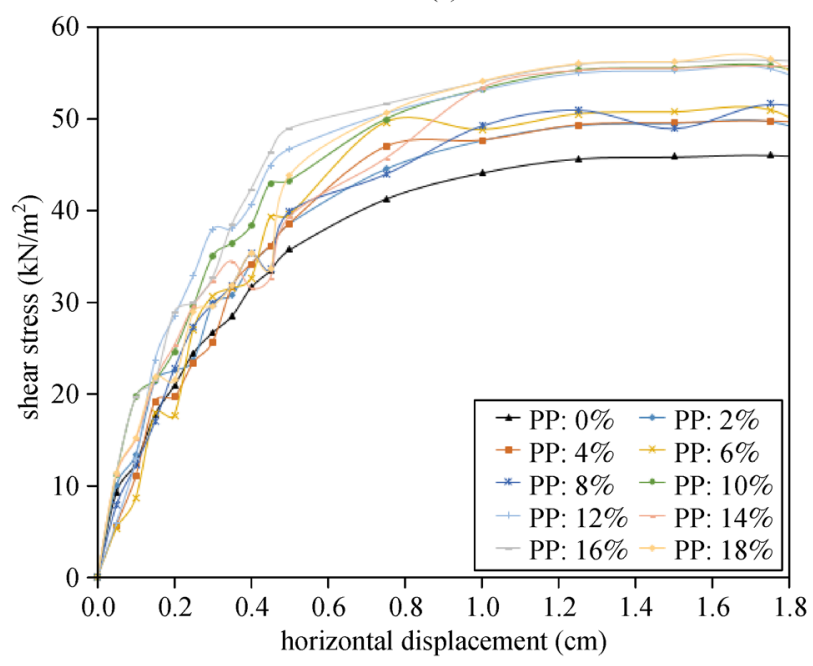

(b)

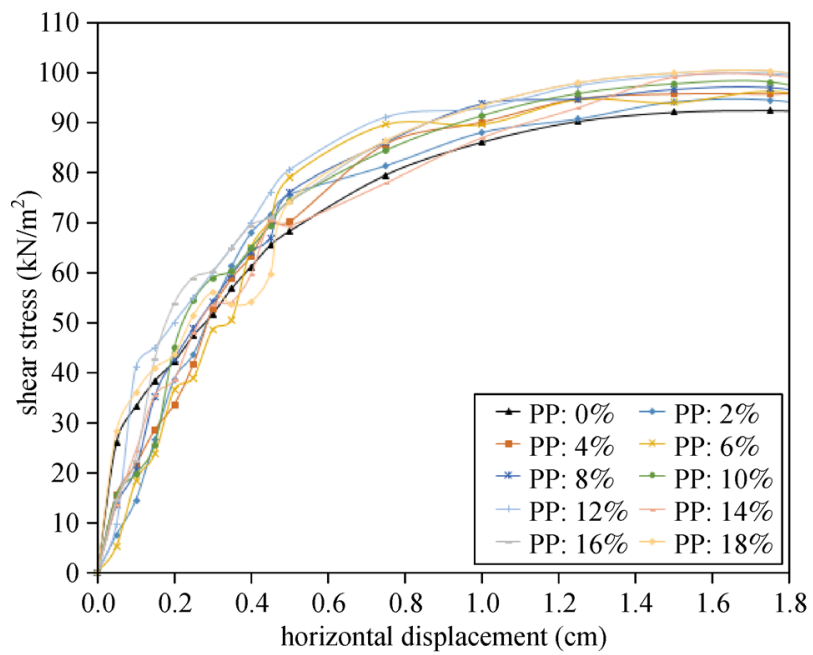

(c)

Fig. 6 Shear stress and horizontal displacement at different PP ratios: (a) normal stress: $28 \mathrm{kN} / \mathrm{m}^{2}$; (b) normal stress: $56 \mathrm{kN} / \mathrm{m}^{2}$; (c) normal stress: $116 \mathrm{kN} / \mathrm{m}^{2}$. 


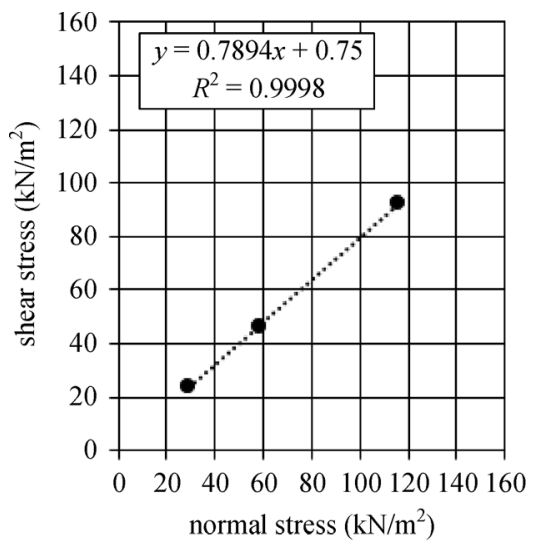

(a)

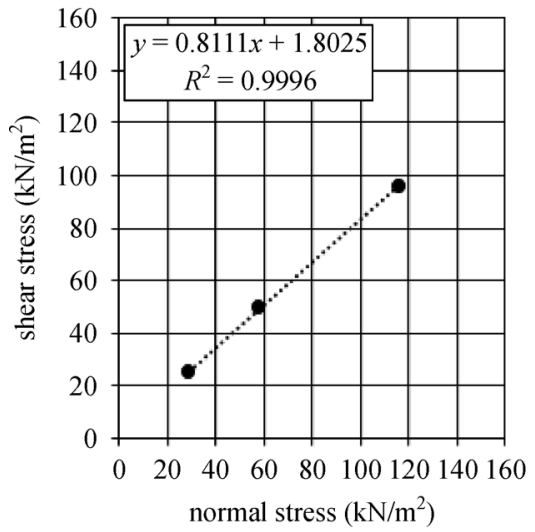

(c)

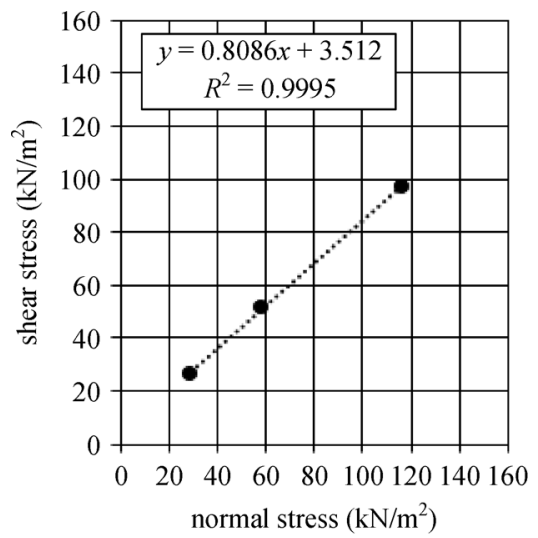

(e)

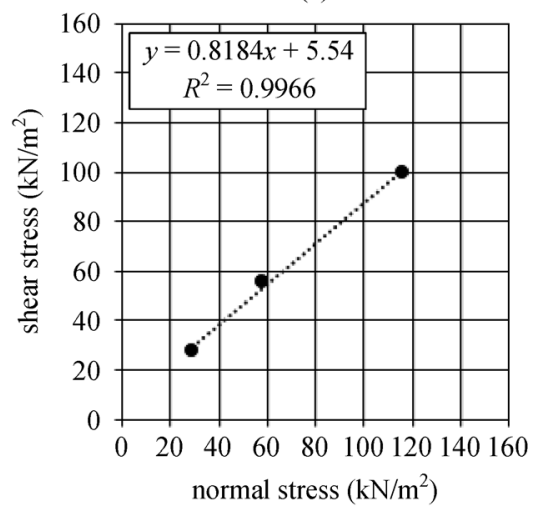

(g)

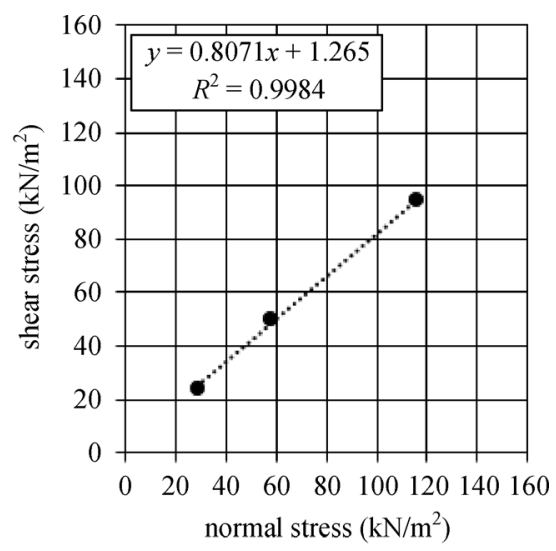

(b)

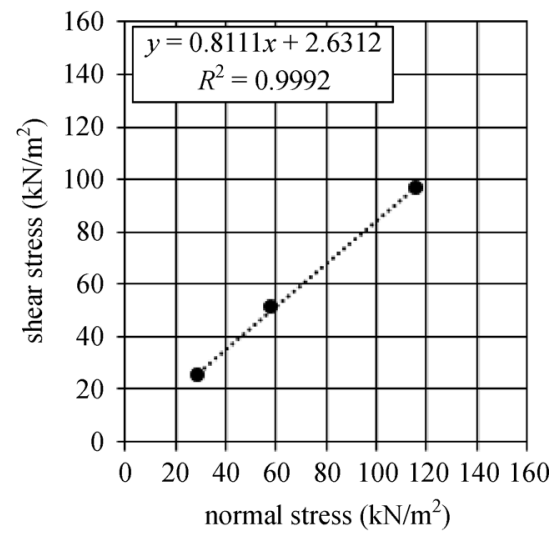

(d)

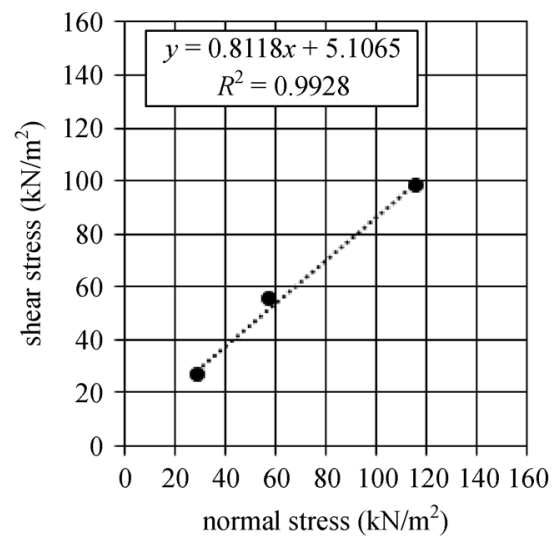

(f)

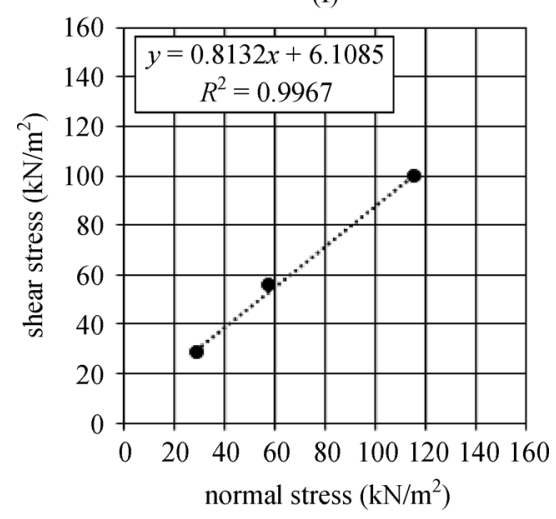

(h) 


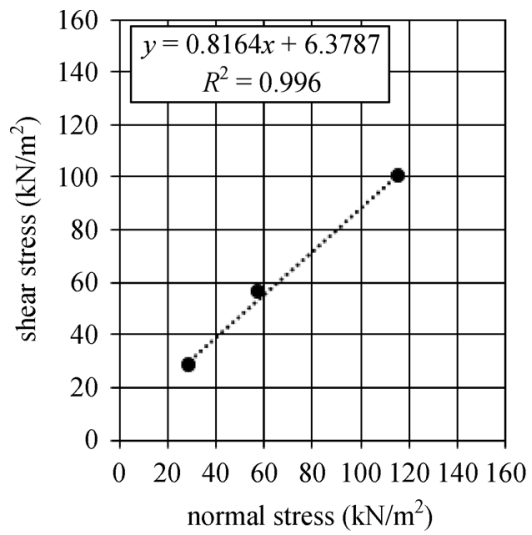

(i)

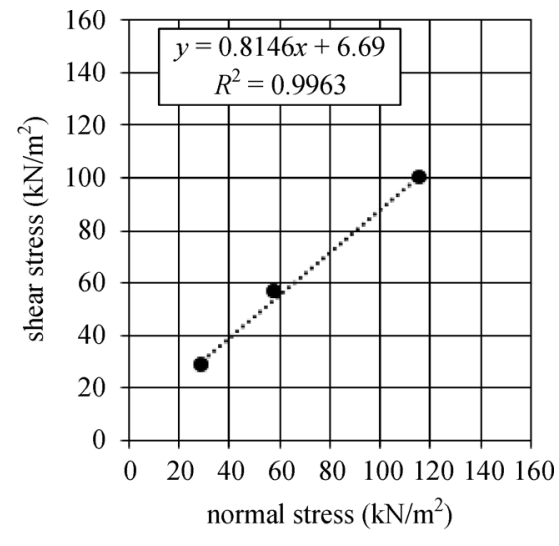

(j)

Fig. 7 Shear-normal stress relations at different PP ratios: (a) $0 \%$; (b) $2 \%$; (c) $4 \%$; (d) $6 \%$; (e) $8 \%$; (f) $10 \%$ : (g) $12 \%$; (h) $14 \%$; (i) $16 \%$; (j) $18 \%$.

Table 2 Changes in $c, \varphi, \tau$, and increments of $\tau$ for different mixing ratios $(\tau=c+\sigma \tan \varphi)$

\begin{tabular}{lcccccccc}
\hline mixing ratio $(\%)$ & $c\left(\mathrm{kN} / \mathrm{m}^{2}\right)$ & $\phi\left({ }^{\circ}\right)$ & $\tau_{1}\left(\mathrm{kN} / \mathrm{m}^{2}\right)$ & increment of $\tau_{1}(\%)$ & $\tau_{2}\left(\mathrm{kN} / \mathrm{m}^{2}\right)$ & increment of $\tau_{2}(\%)$ & $\tau_{3}\left(\mathrm{kN} / \mathrm{m}^{2}\right)$ & increment of $\tau_{3}(\%)$ \\
\hline 0 & 0.75 & 38.30 & 22.9 & - & 46.6 & - & 92.4 \\
2 & 1.26 & 38.90 & 23.9 & 4.37 & 48.1 & 3.22 & 95.4 \\
4 & 1.80 & 39.05 & 24.5 & 6.99 & 48.9 & 4.94 & 95.9 \\
6 & 2.63 & 39.05 & 25.3 & 10.48 & 49.7 & 6.65 & 96.7 \\
8 & 3.51 & 38.95 & 26.1 & 13.97 & 50.4 & 8.15 & 97.3 & 5.65 \\
10 & 5.11 & 39.07 & 27.8 & 21.40 & 52.2 & 12.02 & 99.3 \\
12 & 5.54 & 39.30 & 28.5 & 24.45 & 53.0 & 13.73 & 100.5 \\
14 & 6.11 & 39.11 & 28.9 & 26.20 & 53.3 & 14.38 & 100.4 \\
16 & 6.38 & 39.23 & 29.2 & 27.51 & 53.7 & 15.24 & 8.77 \\
\hline
\end{tabular}

Note: $c$ : cohesion, $\phi$ : internal friction angles, $\sigma$ : normal stress, $\tau$ : shear stress.

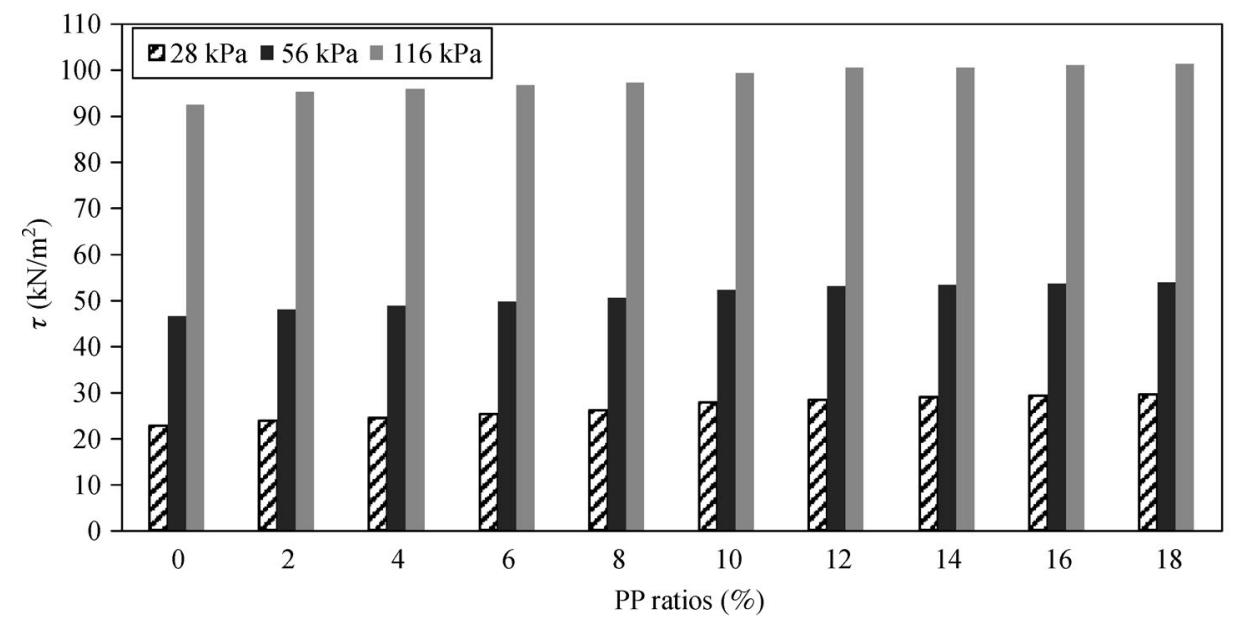

Fig. 8 Shear stress vs vertical stress for different mixing ratios. 
no significant increase after $12 \%$ PP substitution. According to the results, $12 \%$ was selected as the optimum ratio for the model tests (Fig.9).

\subsection{Performances of soils in model tests}

In the first stage, to determine the effect of PP substitution on the bearing capacity of the soil samples, the model test box was filled with the sandy soil without PP as the reference, which was then tested. Next, the model test box was filled with sandy soil containing $12 \%$ PP (the optimum PP ratio) as a substitution material, which was then tested and compared with the reference. The results are depicted in Fig. 10.

As shown in Fig. 10, the maximum stress on the foundation seated on the reference sample was $168 \mathrm{kN} / \mathrm{m}^{2}$ [44] and that of the reinforced sample was $220 \mathrm{kN} / \mathrm{m}^{2}$. Thus, the inclusion of PP increased the maximum strength of sandy soil by $30.7 \%$. Although the soil performance was improved, it was also important to determine the sufficient depth required for optimum improvement. Thus, although a strengthening depth equal to the foundation width is generally considered sufficient in terms of the bearing capacity of foundations, various previous studies did not examine the strengthening depth. Das and Sobhan [45] reported a stress increase under circular loads in unimproved soils of $28.45 \%$ at $1.0 \mathrm{D}$ depth and $19.96 \%$ at 1.25 $D$ depth. Similar results were reported by Bağraç̧ı and Laman [46]. They reported that the stress increase under

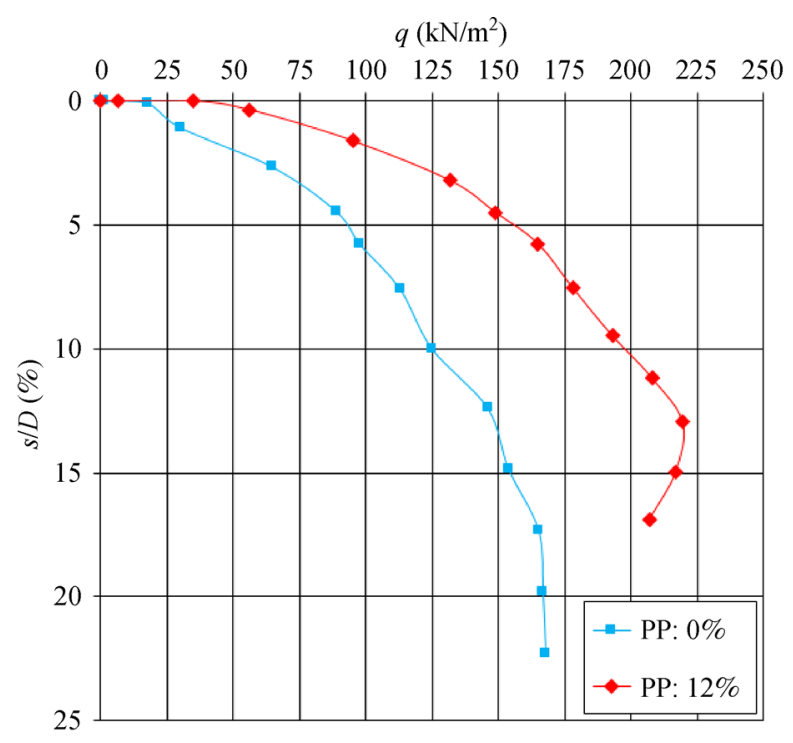

Fig. 10 Stress $(q)$-settlement $(s / D)$.

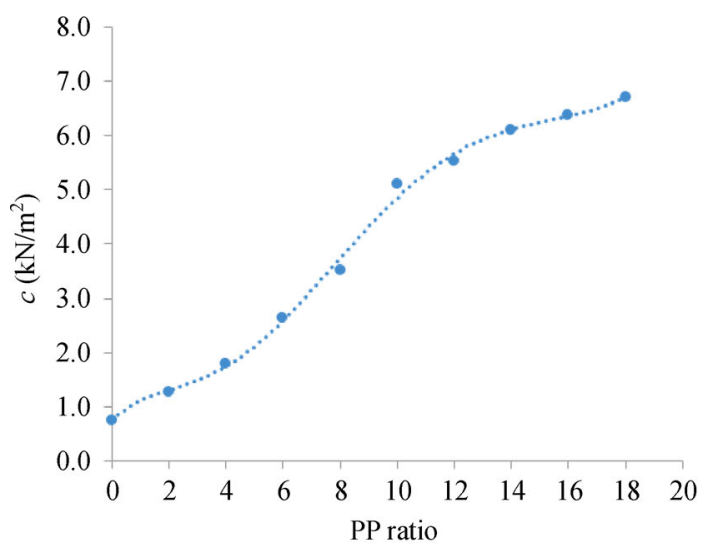

(a)

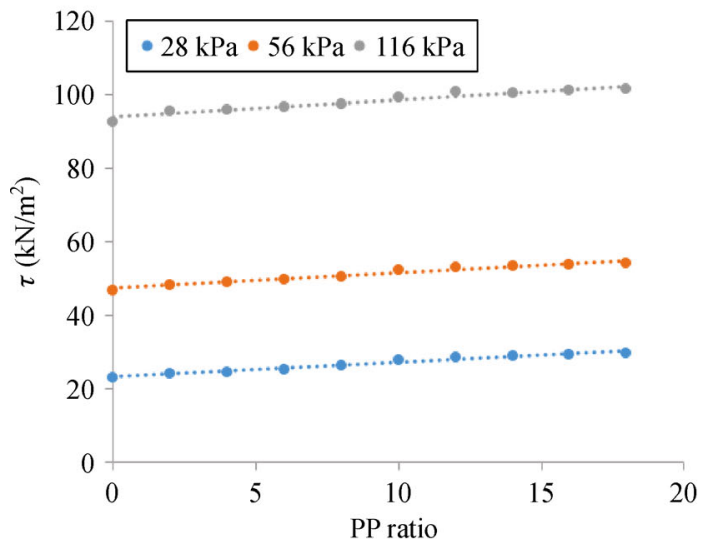

(c)

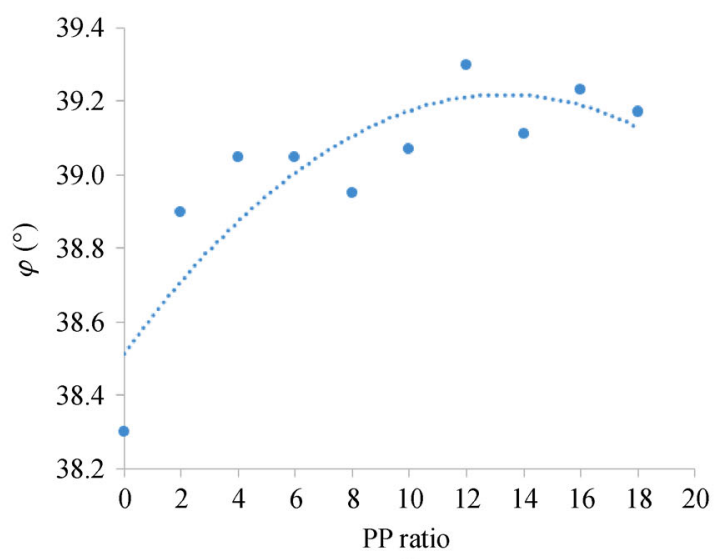

(b)

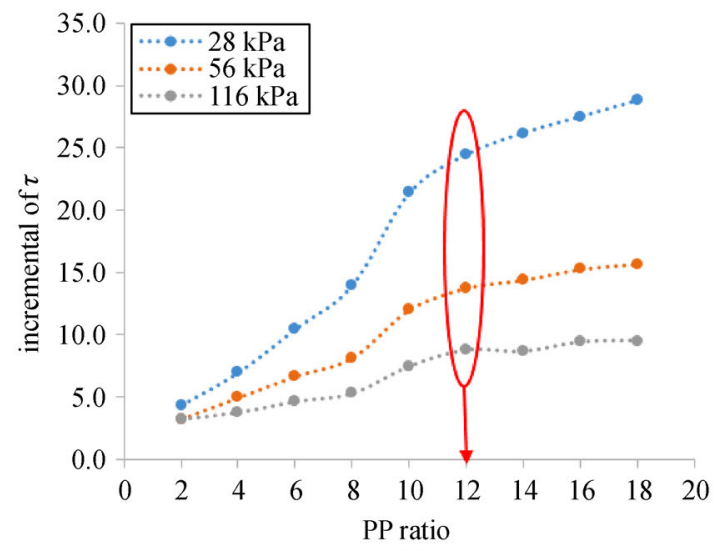

(d)

Fig. 9 Values (a) $c$; (b) $\phi$; (c) $\tau$; (d) increment of $\tau$ for different mixing ratios (\%). 
circular load in unreinforced soils was $23.48 \%$ at $1.0 D$ depth and $17.12 \%$ at $1.25 \mathrm{D}$ depth. They also reported that the applied stress was $10.76 \%$ at $1.0 D$ depth and $8.81 \%$ at $1.25 \mathrm{D}$ depth in improved soils. These studies show that 1.25 is a critical ratio beyond which the stress increase is negligible. In this study, 1.25 was also found as the critical improvement depth ratio, as shown in Figs. 11 and 12. As the depth increased, the increase in the shear strength of the soils and decrease in the rate of increase in stress which is caused by the stress applied from the foundation indicated that the bearing capacity and settlement problems would remain to a certain depth. Therefore, it is very important to determine improvement depth.

To find the critical improved soil depth, the depth of the improved soil $(H)$ was varied and different $H / D$ ratios $(0.25,0.50,0.75,1.00,1.25$, and 1.50$)$ were experimentally investigated. The results for the stress $(q)$ and settlement ratios obtained in the model tests for different $H / D$ values are shown in Fig. 11 . The $H / D$ of 0.00 and 6.00 shown in the graph represent the reference and fully reinforced soil samples, respectively.

Using the data from Fig. 11, the $q-H / D$ graph (Fig. 12) was plotted to obtain the optimum reinforcement depth for site applications. Figure 12 shows a significant increase in the bearing capacity up to $H / D$ of 1.25 . Beyond this value, no significant increase in the bearing capacity was observed, and thus, this ratio could be selected as the optimum reinforcement depth.

\subsection{Microstructural analysis}

As mentioned above, PP is a waste product of cutting and milling during the manufacture of GRP pipes. Chopped glass fibers, silica sand, and unsaturated polyester resin are used in the production of GRP pipes. Hence, the PP used in

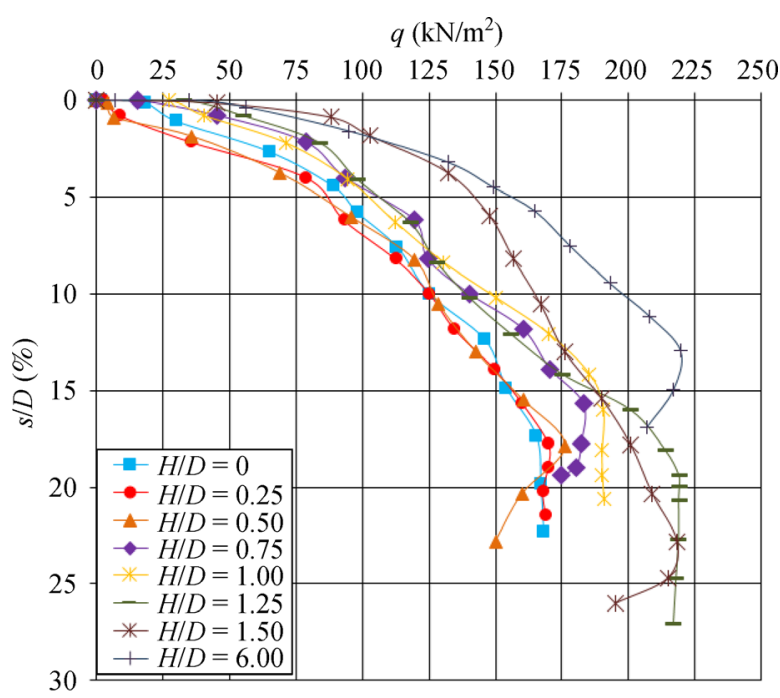

Fig. 11 Stress $(q)$-settlement $(s / D)$ for different reinforcement depths $(H / D)$. this research contained micro-CGFs, silica sand particles (SSPs), and resin residues (RRs). Some SSPs and RRs firmly adhere to the surface of the micro-CGFs, as shown in Fig. 13(b).

The SEM images of the PP-substituted sand soil samples are shown in Fig. 13. The SEM analyses were performed using SEM model FEI-QUANTAFEG-650. The microCGFs had a homogeneous and multiaxial distribution within the soil samples. The multiaxial distribution is an important parameter for improving the bearing capacity of PP-substituted sandy soils. Moreover, some SSPs and RRs were bonded to the micro-CGFs, as shown in Fig. 13(c). These bonded RRs contributed to the bonding between the soil particles, which improved the bearing capacity of the soil.

Figure 13 shows that PP increased cohesion in the soils, which can be attributed to the surface structure of PP. As mentioned above, the PP used in this research contained micro-CGFs, and the SSPs and RRs firmly adhered to the surface of the micro-CGFs. The improvement in the mechanical performance of the PP-containing soils could be attributed to the cohesion formed on the PP surface, as an increased cohesion in soils directly boosts their shear strength. Some previous studies have analyzed the internal structure of fiber-reinforced composite materials using fracture mechanics-based approaches [47]. From the results of this study, there is a need for in-depth analyses of the relationship between fibers and soil performance by fracture-energy modeling.

\section{Conclusions}

In this study, we used PP waste from the cutting and milling processes during the manufacture of GRP pipes as an additive to improve soil performance. The PP was

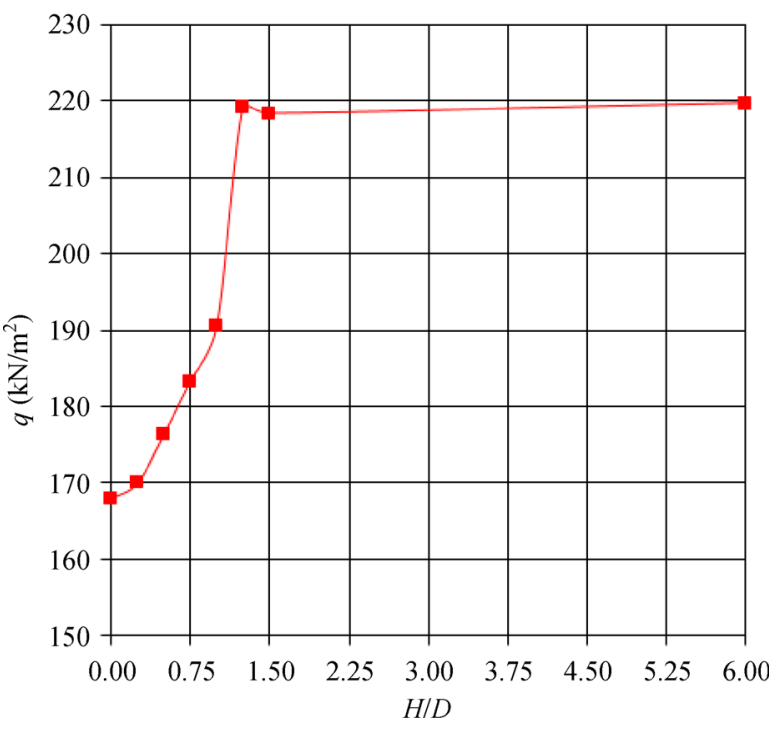

Fig. 12 Bearing capacity $(q)$ for different reinforcement depths $(H / D)$. 


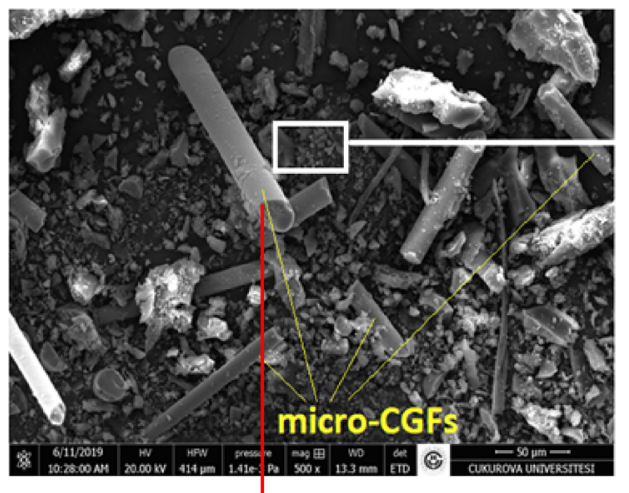

(a)

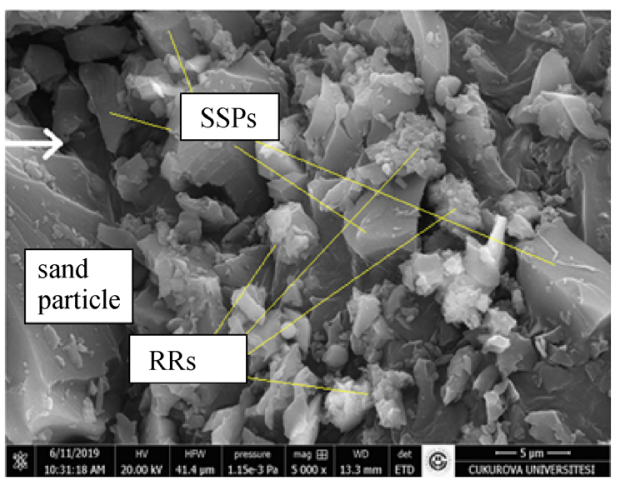

(b)

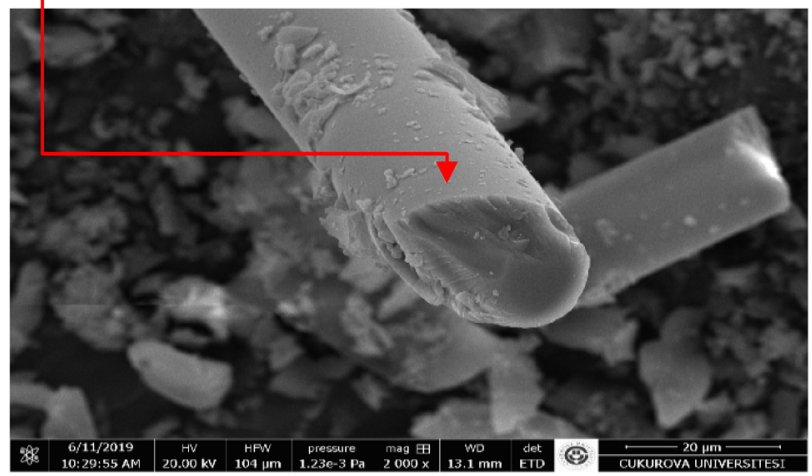

(c)

Fig. 13 SEM images of PP-substituted sandy soil samples.

added to a sandy soil sample in the ratios of $2 \%, 4 \%, 6 \%$, $8 \%, 10 \%, 12 \%, 14 \%, 16 \%$, and $18 \%$ to find its optimum ratio in sandy soil. The bearing capacity of reinforced sandy soil was evaluated for each additive ratio using the internal friction angle and cohesion, and the optimum PP ratio was determined. Then, using the optimum PP ratio, the bearing capacity of the soil was determined through a series of loading tests on a shallow foundation model placed in a test box.

From the experimental results and microstructural analysis, the following conclusions can be drawn.

1) The highest internal friction angle was $39.30^{\circ}$ when $\mathrm{PP}$ was added. Considering this value, the optimum ratio of PP to improve the engineering properties of sandy soils was $12 \%$.

2) According to the model test, the maximum bearing capacity of the soil was $220 \mathrm{kN} / \mathrm{m}^{2}$; thus, the bearing capacity of the sandy soil could be improved by up to $30.7 \%$ using $\mathrm{PP}$ as an additive.

3) Experimental studies conducted at different $H / D$ ratios showed that when PP is used at the optimal level, $H /$ $D$ of 1.25 is sufficient to strengthen the sandy soil.

4) Microstructural analysis showed that the PP used here consisted of micro-CGFs, SSPs, and RRs, and the SSPs and RRs firmly adhered to the surface of the micro-CGFs.

5) The PP exhibited a homogeneous and versatile distribution within the soil. Its multiaxial distribution in the soil contributed to the improvement of the shear strength parameters of sandy soil.

6) In addition to improving the engineering properties of soils, using PP as an additive in soil reduces the environmental impact of this industrial waste; thus, it serves a twofold benefit.

Acknowledgements This study was supported by the Polish National Agency for Academic Exchange under Grant No. PPI/APM/2019/1/00003. The authors thank the management of Superlit Pipe Industry Inc. for providing the PP used in the study.

Open Access This article is licensed under a Creative Commons Attribution 4.0 International License (https://creativecommons.org/licenses/ by/4.0/), which permits use, sharing, adaptation, distribution and reproduction in any medium or format, as long as you give appropriate credit to the original author(s) and the source, provide a link to the Creative Commons licence, and indicate if changes were made. The images or other third party material in this article are included in the article's Creative Commons licence, unless indicated otherwise in a credit line to the material. If material is not included in the article's Creative Commons licence and your intended use is not permitted by statutory regulation or exceeds the permitted use, you will need to obtain permission directly from the copyright holder. To view a copy of this licence, visit http://creativecommons.org/licenses/by/4.0/.

\section{References}

1. Chen C, Wu L, Perdjon M, Huang X, Peng Y. The drying effect on 
xanthan gum biopolymer treated sandy soil shear strength. Construction \& Building Materials, 2019, 197: 271-279

2. Behnood A. Soil and clay stabilization with calcium-and noncalcium-based additives: A state-of-the-art review of challenges, approaches and techniques. Transportation Geotechnics, 2018, 17: $14-32$

3. Hataf N, Ghadir P, Ranjbar N. Investigation of soil stabilization using chitosan biopolymer. Journal of Cleaner Production, 2018, 170: $1493-1500$

4. Xu R, Guo Y, Liu Z. Mechanical properties of stabilized artificial organic soil. Frontiers of Architecture and Civil Engineering in China, 2008, 2(2): 161-165

5. Zhang D M, Yin Z Y, Hicher P Y, Huang H W. Analysis of cementtreated clay behavior by micromechanical approach. Frontiers of Structural and Civil Engineering, 2013, 7(2): 137-153

6. Hino T, Jia R, Sueyoshi S, Harianto T. Effect of environment change on the strength of cement/lime treated clays. Frontiers of Structural and Civil Engineering, 2012, 6(2): 153-165

7. Choobbasti A J, Samakoosh M A, Kutanaei S S. Mechanical properties of soil stabilized with nano calcium carbonate and reinforced with carpet waste fibers. Construction \& Building Materials, 2019, 211: 1094-1104

8. Fatehi H, Abtahi S M, Hashemolhosseini H, Hejazi S M. A novel study on using protein-based biopolymers in soil strengthening. Construction \& Building Materials, 2018, 167: 813-821

9. Li C, Bai S, Zhou T, Liu H, Qin X, Liu S, Liu X, Xiao Y. Strengthincrease mechanism and microstructural characteristics of a biotreated geomaterial. Frontiers of Structural and Civil Engineering, 2020, 14(3): 599-608

10. Alhaji M M, Alhassan M. Effect of reclaimed asphalt pavement stabilization on the microstructure and strength of black cotton soil. International Journal of Technology, 2018, 9(4): 722-736

11. Yokohama S, Sato A. Cyclic mechanical properties of sandy soils by mixing recycled asphalt pavement material. International Journal of GEOMATE, 2019, 16(58): 41-47

12. Badrawi E F, El-kady M S. Stabilizing soft clay using geo-foam beads and cement bypass dust. Underground Space, 2020, 5(4): 292-297

13. Hassan M E, Fayed A L, El-Latif M Y A. Compaction properties of cement kiln dust. In: Proceedings of the 2nd GeoMEast International Congress and Exhibition on Sustainable Civil Infrastructures. Springer, 2018, 225-239

14. Arora S, Kumar A. Bearing capacity of strip footing resting on fibrereinforced pond ash overlying soft clay. Innovative Infrastructure Solutions, 2019, 4(34): 1-11

15. Salimi M, Ghorbani A. Mechanical and compressibility characteristics of a soft clay stabilized by slag-based mixtures and geopolymers. Applied Clay Science, 2020, 184: 105390

16. Toda K, Sato H, Weerakoon N, Otake T, Nishimura S, Sato T. Key factors affecting strength development of steel slag-dredged soil mixtures. Minerals (Basel), 2018, 8(174): 1-16

17. Wu J, Liu Q, Deng Y, Yu X, Feng Q, Yan C. Expansive soil modified by waste steel slag and its application in subbase layer of highways. Soil and Foundation, 2019, 59(4): 955-965

18. Abbaspour M, Aflaki E, Moghadas Nejad F. Reuse of waste tire textile fibers as soil reinforcement. Journal of Cleaner Production,
2019, 207: 1059-1071

19. Akbarimehr D, Aflaki E, Eslami A. Experimental investigation of the densification properties of clay soil mixes with tire waste. Civil Engineering Journal, 2019, 5(2): 363-372

20. Naseem A, Mumtaz W, Fazal-e-Jalal, De Backer H. Stabilization of expansive soil using tire rubber powder and cement kiln dust. Soil Mechanics and Foundation Engineering, 2019, 56(1): 54-58

21. Jose J, Jose A, Kurian J M, Francis J, James S K. Stabilization of expansive soil using fly ash. International Research Journal Engineering Technology, 2018, 5: 3075-3078

22. Striprabu S, Taib S N, Norazzlina M, Fauziah A. Chemical stabilization of Sarawak clay soil with class F fly ash. Journal of Engineering Science and Technology, 2018, 13(10): 3029-3042

23. Brahmachary T K, Ahsan M K, Rokonuzzaman M. Impact of rice husk ash (RHA) and nylon fiber on the bearing capacity of organic soil. SN Applied Sciences, 2019, 1(3): 1-13

24. Brooks R M. Soil stabilization with fly ash and rice husk ash. International Journal of Research and Reviews in Applied Sciences, 2009, 1(3): 209-217

25. Pastor J L, Tomás R, Cano M, Riquelme A, Gutiérrez E. Evaluation of the improvement effect of limestone powder waste in the stabilization of swelling clayey soil. Sustainability, 2019, 11(679): $1-14$

26. Zainuddin N, Mohd Yunus N Z, Al-Bared M A M, Marto A, Harahap I S H, Rashid A S A. Measuring the engineering properties of marine clay treated with disposed granite waste. Measurement, 2019, 131: 50-60

27. Arulrajah A, Mohammadinia A, D'Amico A, Horpibulsuk S. Effect of lime kiln dust as an alternative binder in the stabilization of construction and demolition materials. Construction \& Building Materials, 2017, 152: 999-1007

28. Mohammadinia A, Arulrajah A, Haghighi H, Horpibulsuk S. Effect of lime stabilization on the mechanical and micro-scale properties of recycled demolition materials. Sustainable Cities and Society, 2017, 30: $58-65$

29. Sharma A, Sharma R, Bhardwaj A. Effect of Construction Demolition and Glass Waste on Stabilization of Clayey Soil. In: Proceedings of the 1st International Conference on Sustainable Waste Management through Design IC_SWMD 2018. Springer, 2019, 21: 87-94

30. Canakci H, AL-Kaki A, Celik F. Stabilization of clay with waste soda lime glass powder. Procedia Engineering, 2016, 161: 600605

31. Fauzi A, Djauhari Z, Juniansyah Fauzi U. Soil engineering properties improvement by utilization of cut waste and crushed waste glass as additive. IACSIT International Journal of Engineering and Technology, 2016, 8(1): 15-25

32. Güllü H, Canakci H, Al Zangana I F. Use of cement-based grout with glass powder for deep mixing. Construction \& Building Materials, 2017, 137: 12-20

33. Parihar N S, Garlapati V K, Ganguly R. Stabilization of Black Cotton Soil Using Waste Glass. Handbook of Environmental Materials Management, 2018, 1-16

34. Arulrajah A, Kua T A, Suksiripattanapong C, Horpibulsuk S. Stiffness and strength properties of spent coffee grounds-recycled glass geopolymers. Road Materials and Pavement Design, 2019, 
20(3): 623-638

35. Atahu M, Saathoff F, Gebissa A. Strength and compressibility behaviors of expansive soil treated with coffee husk ash. Journal of Rock Mechanics and Geotechnical Engineering, 2019, 11(2): 337348

36. Superlit GRP Pipe Production Factory Research and Development Department. Technical document. Düzce: Superlit Pipe Industry Inc., 2019

37. ASTM 6913-04 AD. Standard Test Methods for Particle-size Distribution (Gradation) of Soils Using Sieve Analysis. West Conshohocken, PA: ASTM International, 2009

38. ASTM D7263-09. Standard Test Methods for Laboratory Determination of Density (Unit Weight) of Soil Specimens. West Conshohocken, PA: ASTM International, 2009

39. ASTM D4253-16. Standard Test Methods for Maximum Index Density and Unit Weight of Soils Using a Vibratory Table. West Conshohocken, PA: ASTM International, 2016

40. ASTM D4254-16. Standard Test Methods for Minimum Index Density and Unit Weight of Soils and Calculation of Relative Density. West Conshohocken, PA: ASTM International, 2016

41. Bağrıaçık B, Yıldırım Z B, Güner E D, Beycioğlu A. Assessment of pipe powder in soil improvement applications: An optimization by response surface methodology. Arabian Journal of Geosciences, 2020, 13(1035): 1-11

42. Beycioğlu A, Kaya O, Yıldırım Z B, Bağrıaçık B, Dobiszewska M, Morova N, Çetin S. Use of GRP pipe waste powder as a filler replacement in hot-mix asphalt. Materials (Basel), 2020, 13(4630): $1-15$

43. ASTM D3080. A Standard Test Method for Direct Shear Test of Soils under Consolidated Drained Conditions. West Conshohocken, PA: ASTM International, 1998

44. Bagriacik B, Mahmutluoglu B. A new experimental approach to the improvement of sandy soils with construction demolition waste and cement. Arabian Journal of Geosciences, 2020, 13(539): 1-11

45. Das B M, Sobhan K. Principles of Geotechnical Engineering. Bosten: Cengage Learning, 2016, 845

46. Bağrıaçık B, Laman M. Distribution of stresses in unreinforced and reinforced soils induced by a circular foundation. Journal of the Faculty of Engineering and Architecture of Gazi University, 2011, 26(4): 787-800

47. Msekh M A, Cuong N H, Zi G, Areias P, Zhuang X, Rabczuk T. Fracture properties prediction of clay/epoxy nanocomposites with interphase zones using a phase field model. Engineering Fracture Mechanics, 2018, 188: 287-299 